\title{
The characteristics of a national register of people with multiple sclerosis (MS): A comparison between the ARMS (Action for Research into Multiple Sclerosis) register and 10 British MS populations
}

\author{
JUDITH MONKS AND IAN ROBINSON \\ From Brunel-ARMS Research Unit, Brunel, The University of West London, Middlesex.
}

ABSTRACT Problems with case ascertainment in epidemiological research on multiple sclerosis (MS) make it necessary to use indirect sources. However there is a lack of information about the characteristics of cases drawn from different sources and thus little basis on which sampling frames for large scale surveys may be constructed. The characteristics of a population drawn from the membership of Action for Research into Multiple Sclerosis (ARMS) were compared with those of 10 other British MS populations reported between 1980 and 1987. Demographic variables examined were geographical location, nationality, ethnicity, sex ratio and age. Diagnostic status, age at diagnosis and duration since diagnosis were considered together with data on the comparative populations based on date of onset. On all the variables investigated the ARMS population fell close to or within the range shown by the comparative populations. The relative youth of the ARMS population and its bias towards a high proportion of females were differences in keeping with existing knowledge about the membership of mutual support organisations. A population drawn from such an organisation may usefully complement other MS research populations provided that the likely biases in each are understood.

The particular problems encountered in epidemiological research on multiple sclerosis (MS) have been summarised by Matthews et al. ${ }^{1}$ They relate firstly to the lack of any diagnostic test with acceptable specificity and sensitivity, secondly to the low prevalence of the condition, which often necessitates case finding through a range of agencies, and thirdly to the frequently substantial interval between the appearance of initial symptoms and the confirmation of the diagnosis. The latter inevitably means the exclusion of undiagnosed cases, as well as the inclusion of misdiagnosed cases in any prevalence estimate. The problems of epidemiological research in MS have recently been compounded by the necropsy finding of histopathological features of the disease in cases with no prior record of associated symptoms, and by recent work based on nuclear magnetic resonance imaging and other techniques which have similarly revealed multiple lesions in largely asymptomatic cases. ${ }^{23}$ Both these observations suggest that complete case ascertainment of MS in population based studies is unlikely, using any currently practicable techniques.

The second of the problems noted by Matthews et al (low prevalence) is, as the authors point out, compounded by the concurrent low incidence of the disease. Given diagnostic difficulties, incidence in multiple sclerosis is if anything even more difficult to estimate than prevalence, requiring long term observation of a large sized population. Prevalence estimates therefore assume a particular significance in spite of their known limitations.

This paper addresses one of the inherent problems of prevalence studies of multiple sclerosis highlighted by Matthews et al, that of the need to use indirect methods of case identification. Common sources of indirect case referral are the records of hospital and community health services and local branches of the Multiple Sclerosis Society. Social Services Department records might be used to a lesser extent (examples of studies and sources are indicated in table 1). With the lack of any comprehensive notification procedure for MS, the use of multiple sources is probably the most feasible method of reaching an epidemiologically acceptable level of case detection, ensuring as far as possible both comprehensiveness and the reduction of bias. Examples of biases are found for instance, in hospital or physician referred populations which have been noted for their probable 
exclusion of patients with minor symptoms, ${ }^{45}$ and in patient support groups which, it has been argued, have a membership which tends to be young and female. ${ }^{6}$ However there has been little detailed study of the features on which populations drawn from various sources might differ, and thus little basis on which sampling frames for surveys requiring more than a restricted geographical population base (for comparison of service provision for example) may be constructed.

The following discussion analyses the characteristics of a sample drawn from one unconventional source of cases of MS - that of a Register of people with the disease who also belong to a national mutual support organisation, Action for Research into Multiple Sclerosis (ARMS). The population characteristics in terms of demography and diagnostic status are compared with those of 10 other MS populations used in research reported between 1980 and 1987 (table 1), ${ }^{4-15}$ a procedure which has highlighted a range of methodological issues relevant to case identification and population description. Research reports were located using the MEDLINE database, Multiple Sclerosis Indicative Abstracts $^{16}$ and Multiple Sclerosis Research Reports. ${ }^{17}$ Only epidemiological surveys and other studies not using explicitly selected patient populations were reviewed. Therefore controlled trials and small studies involving only single centre populations were omitted.

\section{Methods}

The ARMS Research Register was established in 1981 and incorporated those ARMS members with multiple sclerosis who had, on joining, agreed to participate in research. There is no reason to suspect any discrepancy between those who agreed to participate (the majority) and those who did not; it appears that participation in research was treated as one of the "standard" benefits of joining the organisation. Two major studies on the Register membership are relevant to the epidemiological description reported here and the methods relating to each are described separately below.

RESEARCHING THE DEMOGRAPHIC CHARACTERISTICS OF REGISTER MEMBERS

In November 1984 a self completion demographic questionnaire was mailed to all current Register members (1481) as part of a set of four questionnaires initiating a longitudinal survey of self assessed health and disability status. Seventy three per cent (1085) returned the demographic questionnaire. Table 2 gives reasons for non-response and shows how the changed circumstances of some members since the previous

Table 1 British surveys using multiple sclerosis populations, 1980-1987

\begin{tabular}{|c|c|c|c|}
\hline Author $(s)$ and publication date & Location & Population size & Source (s) of cases \\
\hline Davoud N, Kettle M, $1980^{7}$ & Britain & 1243 & Multiple Sclerosis Society \\
\hline Poskanzer DC et al, $1980^{8}$ & Orkney and Shetland Isles & $\begin{array}{ll}\text { Orkney } & : 71 \\
\text { Shetland } & : 55\end{array}$ & $\begin{array}{l}\text { General practitioner records } \\
\text { Public health nursing records } \\
\text { Local MS societies }\end{array}$ \\
\hline Roberts DF, $1980^{9}$ & Orkney and Shetland Isles & $\begin{array}{ll}\text { Orkney } & : 51 \\
\text { Shetland } & : 33\end{array}$ & $\begin{array}{l}\text { Previous surveys } \\
\text { General practitioner records }\end{array}$ \\
\hline Shepherd DI, Downie AW, $1980^{10}$ & NE Scotland & 634 & $\begin{array}{l}\text { Previous survey (which used hospital } \\
\text { and general practitioner records) }\end{array}$ \\
\hline Dean G et al, $1981^{11}$ & Western Isles & 34 & $\begin{array}{l}\text { Hospital records } \\
\text { General practitioner records }\end{array}$ \\
\hline Shibasaki H et al, $1981^{4}$ & London & 204 & Hospital records \\
\hline Roberts DF, Bates D, $1982^{12}$ & NE England & 206 & Hospital records \\
\hline Cook SD et al, $1985^{13}$ & Orkney Isles & 43 & $\begin{array}{l}\text { Previous surveys } \\
\text { Hospital records } \\
\text { General practitioner records } \\
\text { Local MS society }\end{array}$ \\
\hline Williams ES, McKeran RO, $1986^{14}$ & London borough (Sutton) & 195 & $\begin{array}{l}\text { Hospital records } \\
\text { General practitioner records } \\
\text { Community nursing records } \\
\text { Social Services Department } \\
\text { MS Society (local branch) }\end{array}$ \\
\hline Phadke JG, Downie AW, $1987^{15}$ & NE Scotland & 839 & $\begin{array}{l}\text { Previous surveys } \\
\text { Hospital records } \\
\text { General practitioner records } \\
\text { Community nursing records } \\
\text { MS Society (local branch) }\end{array}$ \\
\hline
\end{tabular}


Table 2 Demographic survey 1984/5: Sex and age distribution of non-respondents

\begin{tabular}{|c|c|c|c|c|c|}
\hline \multirow{3}{*}{$\frac{\text { Reason for loss to survey }}{\text { Incorrect diagnosis }}$} & \multicolumn{3}{|l|}{$\operatorname{Sex}$} & \multicolumn{2}{|c|}{ Age (years) } \\
\hline & \multirow{2}{*}{ Men } & \multirow{2}{*}{ Women } & \multirow{2}{*}{$\frac{(\text { Total) }}{(4)}$} & \multirow{2}{*}{$\frac{\text { Mean }}{35 \cdot 0}$} & Range (n) \\
\hline & & & & & $34-37$ \\
\hline Died prior to survey & 9 & 7 & (16) & $54 \cdot 5$ & $32-73 \quad$ (13) \\
\hline $\begin{array}{l}\text { Wished to withdraw from } \\
\text { Register }\end{array}$ & 12 & 22 & (34) & $53 \cdot 3$ & $35-71 \quad(26)$ \\
\hline $\begin{array}{l}\text { Returned questionnaire after } \\
\text { closing date }\end{array}$ & 8 & 16 & (24) & $44 \cdot 3$ & $23-63 \quad(15)$ \\
\hline Not traced at previous address & 11 & 36 & (47) & 45.9 & $25-71 \quad(25)$ \\
\hline Traced after closing date & 1 & 6 & (7) & $39 \cdot 1$ & $23-49$ \\
\hline $\begin{array}{l}\text { Returned questionnaire lost in } \\
\text { post }\end{array}$ & - & 1 & (1) & (no ir & nformation) \\
\hline $\begin{array}{l}\text { Did not complete demographic } \\
\text { questionnaire }\end{array}$ & 3 & 3 & (6) & $45 \cdot 0$ & $36-59$ \\
\hline No response & 77 & 180 & (257) & $44 \cdot 6$ & $24-81(161)$ \\
\hline Total & 121 & 275 & (396) & 45.9 & $23-81(253)$ \\
\hline
\end{tabular}

contact 14 months earlier now precluded them from participating. Of the 34 who wished to withdraw from the Register, 11 wished to do so because of deterioration in health and 10 because of difficulties with or dislike of completing the questionnaires. Others found the work involved too demanding in conjunction with their other commitments ${ }^{5}$ or had misunderstood or lost interest in our research. ${ }^{2}$ In six cases the reason for the wish to withdraw was not clear.

The age distribution of non-respondents (table 2) differs little from that of those returning questionnaires, either in terms of the mean or range. The male:female ratio of non-respondents was 1:2.3 compared with 1:3.1 for the survey population and 1:2.8 for the total Register members to whom questionnaires were sent (table 3).

The proportion of non-respondents in a survey will depend largely on the research strategy employed. Data for the MS populations used for comparison with those from the ARMS Register are for the most part based on clinical records or histories taken as part of a single clinical examination and "losses" are thus minimal. The only questionnaire based survey, ${ }^{7}$ which like our own relied on the active cooperation of the participants, did not report on loss. The major reasons for loss in studies where populations were drawn from pre-existing records were similar to those in our own list of categories, and included incorrect diagnosis, death, and incorrect address. ${ }^{8}$ 13-15

CONFIRMING THE DIAGNOSTIC STATUS OF REGISTER MEMBERS

All members of the Register had indicated on joining ARMS that they believed themselves to have multiple sclerosis. It has not proved possible for resource and

Table 3 Sex ratio, age, age at onset and duration of multiple sclerosis for ARMS Research Register membership compared with other MS research populations, 1980-1987

\begin{tabular}{|c|c|c|c|c|c|c|c|c|c|c|}
\hline \multirow[b]{2}{*}{ Population } & \multicolumn{2}{|c|}{ Sex ratio } & \multicolumn{3}{|l|}{ Age (years) } & \multicolumn{4}{|c|}{ Age at onset (years) } & \multirow{2}{*}{$\begin{array}{l}\text { Mean duration } \\
\text { (years) }\end{array}$} \\
\hline & Men: & Women & Mean & (range) & $S D$ & Mean & & & (range) & \\
\hline $\begin{array}{l}\text { ARMS Research Register } \\
\text { Britain, } 1984\end{array}$ & $1:$ & $: 3 \cdot 1$ & $46 \cdot 0$ & $(22-79)$ & $11 \cdot 1$ & $36 \cdot 0^{*}$ & $\begin{array}{l}\text { men } \\
\text { women }\end{array}$ & $\begin{array}{l}36 \cdot 8 \\
35 \cdot 8\end{array}$ & $(14-61)$ & $9 \cdot 7^{*}$ \\
\hline $\begin{array}{l}\text { Davoud N, Kettle M, } \\
\text { Britain, } 1980^{7}\end{array}$ & $1:$ & $: 1 \cdot 3$ & - & - & - & - & & & - & - \\
\hline $\begin{array}{l}\text { Poskanzer DC et al, Orkney, } \\
\text { Shetland, } 1980^{8}\end{array}$ & - & & - & - & - & $\begin{array}{l}33 \cdot 6 \\
29.0\end{array}$ & $\begin{array}{l}\text { Orkney } \\
\text { Shetland }\end{array}$ & & - & - \\
\hline $\begin{array}{l}\text { Roberts DF, Orkney, } \\
\text { Shetland, } 1980^{9}\end{array}$ & $\begin{array}{l}1 \\
1\end{array}$ & $\begin{array}{l}: 1.4 \text { Orkney } \\
: 1.2 \text { Shetland }\end{array}$ & $\begin{array}{l}52.7 \text { Orkney } \\
49.5 \text { Shetland }\end{array}$ & - & - & $\begin{array}{l}29 \cdot 0 \\
33 \cdot 6\end{array}$ & $\begin{array}{l}\text { Orkney } \\
\text { Shetland }\end{array}$ & & - & - \\
\hline $\begin{array}{l}\text { Shepherd DI, Downie AW, } \\
\text { NE Scotland, } 1980^{10}\end{array}$ & $1:$ & $: 1.7$ & 48.6 & $(14-87)$ & - & 33.8 & & & $(11-61)$ & $15 \cdot 3$ \\
\hline $\begin{array}{l}\text { Dean G, et al. } \\
\text { Western Isies, } 1981^{11}\end{array}$ & $1:$ & $: 1 \cdot 3$ & $46 \cdot 3$ & - & - & $35 \cdot 8$ & $\begin{array}{l}\text { men } \\
\text { women }\end{array}$ & $\begin{array}{l}37 \cdot 8 \\
34 \cdot 1\end{array}$ & - & - \\
\hline $\begin{array}{l}\text { Shibasaki H et al, } \\
\text { London, } 1981^{4}\end{array}$ & $1:$ & $: 2.0$ & - & - & - & $31 \cdot 0$ & $\begin{array}{l}\text { men } \\
\text { women }\end{array}$ & $\begin{array}{l}33 \cdot 0 \\
31 \cdot 0\end{array}$ & - & $\begin{array}{l}11.0 \text { (to latest } \\
\text { examination) }\end{array}$ \\
\hline $\begin{array}{l}\text { Roberts DF, Bates } D_{12} \\
\text { NE England, } 1982^{12}\end{array}$ & $1:$ & $: 1.8$ & - & - & - & - & & & - & - \\
\hline Cook SD et al, Orkney, $1985^{13}$ & $1:$ & : $\mathbf{3 . 3}$ & 52.0 & $(18-81)$ & - & 30.0 & & & (15-55) & 22.0 \\
\hline $\begin{array}{l}\text { Williams ES, McKeran RO, } \\
\text { London borough, } 1986^{14}\end{array}$ & $\begin{aligned} 1 & : \\
(1 & :\end{aligned}$ & $\begin{array}{l}: 2.25 \\
: 2 \text { age standardised) }\end{array}$ & 49.0 & $(20-82)$ & 14.4 & $34 \cdot 1$ & $\begin{array}{l}\text { men } \\
\text { women }\end{array}$ & $\begin{array}{l}34 \cdot 8 \\
33 \cdot 7\end{array}$ & $(14-61)$ & 15.4 \\
\hline $\begin{array}{l}\text { Phadke JG, Downie AW, } \\
\text { NE Scotland, } 198715\end{array}$ & $1:$ & $: 1.9$ & 45.1 & $(11-94)$ & - & 34.5 & $\begin{array}{l}\text { men } \\
\text { women }\end{array}$ & $\begin{array}{l}34 \cdot 1 \\
34 \cdot 7\end{array}$ & - & 14.8 \\
\hline
\end{tabular}

- Age at diagnosis and duration since diagnosis. Dates of diagnosis reported as "approximate" or which were otherwise unclear were excluded. Results are based on a population of 425 (39\% of demographic survey population). 
logistical reasons for a member of the research team to confirm the claim of every member of the Register directly either through a neurological examination or through an inspection and analysis of clinical records. It was therefore decided to adopt a multifaceted approach to confirmation which to date has comprised two principal studies. The first study investigated the ways and circumstances in which Register members had been informed about their diagnosis. This study indicated that $95 \%$ had been told formally that they had multiple sclerosis whilst the remainder either discovered the fact accidentally, for instance by seeing their medical records, or through other means. ${ }^{18}$ The second study has involved a survey of Register members' general practitioners to establish the certainty with which a diagnosis had been made.

The survey of general practitioners is being carried out, for resource reasons, in two stages. Stage 1 involved seeking permission from half the Register membership (active on 2nd February 1987 and comprising each alternate member registered) to approach their general practitioner. Each general practitioner was asked to indicate in writing whether the diagnosis was "possible", "probable" or "definite"- a widely recognised, categorisation and one which incorporates the most commonly used terms for indicating diagnostic status. ${ }^{1}$ The date of diagnosis was also requested. This first stage was concluded in February 1988 and a similar procedure is currently being carried out with respect to the remainder of the Register population.

The results of our procedure for obtaining diagnostic confirmation must be regarded as tentative, although the procedure itself has proved a success, involving as it has the active cooperation of hundreds of general practitioners. However there is no evidence that the accuracy of diagnoses obtained by such means is suspect, despite McLellan and Roberts.'19 unsubstantiated claim that general practitioners may sometimes mistakenly believe patients with mild symptoms to have MS. While we acknowledge that the nature and application of the diagnostic criteria used by general practitioners (or the responsible neurologists) to identify patients is unclear, we would also draw attention to the well recognised but under researched problem of categorisation, even with the employment of explicitly defined criteria and clinical examination. ${ }^{120}$

The results of Stage 1 in establishing the diagnostic status of the Register membership are shown in table 4. Confirmation of diagnosis was obtained for 461 (94.7\%) of the 487 members contacted. Of the 26 for whom information was missing, one had died since our previous contact, 11 refused us permission to contact their GP, 10 did not respond to our letter and
Table 4 ARMS Research Register: diagnostic status

\begin{tabular}{lcccccc}
\hline \multicolumn{7}{c}{ Diagnostic status (in 1984) } \\
\cline { 2 - 6 } Sex & Definite & Probable & Possible & Doubtful & Unclear* & Total \\
\hline Female & 287 & 47 & 4 & 2 & 4 & 344 \\
Male & 94 & 6 & - & - & 2 & 102 \\
Total & 381 & 53 & 4 & 2 & 6 & $446 \dagger$ \\
\hline
\end{tabular}

* GP indicated MS diagnosis but no clear category

† Omitted are 15 Register members for whom no date of diagnosis was given or who were placed in a diagnostic category after 1984 .

could not be contacted by telephone, and in five cases the GP failed to respond to our request for confirmation. The sex ratio (1:3.3) and mean age (45.6 years in 1984) of the population whose diagnosis was confirmed corresponds with that of the original cohort (see below).

The confirmatory procedure indicated that the proportions of "definite/probable" and "possible" cases were $97.3 \%$ (434) and $0.9 \%$ (4) respectively amongst those Register members on whom diagnostic information was obtained, with a further $1.3 \%$ (6) whose diagnosis was confirmed without indication of a category. Diagnosis was doubtful in an additional two cases. This compares with a mean of $83 \%$ (range $76-90 \%$ ) for "probable" and $17 \%$ (range $10-24 \%$ ) for "possible" diagnoses in the seven comparative studies where information is available. ${ }^{8-11} 13-15$ Two of these studies $^{811}$ also report cases where MS was not confirmed, even at the level of "possibility".

\section{Results}

AREA OF RESIDENCE, NATIONALITY AND ETHNICITY The geographical location of the Register membership is shown in the figure, and nationality and ethnicity in tables 5 and 6. The vast majority of the members describe themselves as "British" and "white" and are residents within the UK with the heaviest concentration occurring in South and South East England. The member currently living in the USA is of

Table 5 ARMS Research Register: nationality

\begin{tabular}{lc}
\hline Nationality & Number of members \\
\hline British & 1063 \\
Irish & 9 \\
German & 2 \\
Dutch & 1 \\
New Zealander & 1 \\
American & 1 \\
Mixed & 3 \\
Total & $1080^{*}$ \\
\hline
\end{tabular}

* Data missing for 11 members 
Table 6 ARMS Research Register: ethnicity

\begin{tabular}{lc}
\hline Ethnicity & Number of members \\
\hline White & 1069 \\
British Gypsy & 1 \\
Mixed & 4 \\
Total & $1074^{*}$ \\
\hline
\end{tabular}

* Data missing for 17 members.

British nationality (born in Rhodesia) and left Britain in July 1984. The number of members living outside the UK is small and all are currently retained on the Register although they are excluded for particular analyses and for the selection of specific samples. There is no geographical bias amongst the six currently active members who did not complete the demographic questionnaire.

The populations shown in table 1 are described principally in terms of sex ratio and the distributions of current age, age at onset, and duration of multiple sclerosis. In table 3 the characteristics of the ARMS Research Register membership and the selected comparative populations are presented for each of the major descriptive variables.

\section{SEX RATIO}

A previous extensive review of our own indicated the sex ratio in multiple sclerosis to be far more variable than commonly supposed. ${ }^{21}$ The male:female ratio of Register members in the present survey was 1:3.1 against a range of reported values in the comparative studies of $1: 1.2$ to $1: 3.3$. Thus our population is at the higher end of this range. The result from our survey is in keeping with other general indications that those who join mutual support groups tend to be female, although Davoud and Kettle's study, also based on a population drawn from a mutual support group, does not indicate such a bias. ${ }^{7}$

AGE

Further details of the sex and age distribution for Register members are given in table 7 and show the highest frequency of membership to occur within the
$30-49$ years age group with the male population being the marginally older. In table 8 these findings are presented alongside figures for the comparative populations for which these data are available. Overall

Table 8 Age group showing highest prevalence/frequency of MS cases for ARMS Research Register membership compared with other MS research populations, 1980-1987

\begin{tabular}{|c|c|c|}
\hline \multirow[b]{2}{*}{ Population } & \multicolumn{2}{|c|}{$\begin{array}{l}\text { Age group with highest } \\
\text { prevalence/frequency (years) }\end{array}$} \\
\hline & Female & Male \\
\hline ARMS Research Register, Britain, 1984 & $30-39$ & $40-49$ \\
\hline Davoud N, Kettle M, Britain, $1980^{7}$ & $31-50$ & $31-50$ \\
\hline $\begin{array}{l}\text { Shepherd DI, Downie AW. } \\
\text { NE Scotland, } 198010\end{array}$ & $40-49$ & $50-59$ \\
\hline Dean et al, Western Isles, $1981^{11}$ & Mean age 43.5 & Mean age 49.8 \\
\hline $\begin{array}{l}\text { Williams ES, McKeran RO, } \\
\text { London borough, } 1986^{14}\end{array}$ & $45-54$ & $45-54$ \\
\hline $\begin{array}{l}\text { Phadke JG, Downie AW, } \\
\text { NE Scotland, } 1987^{15}\end{array}$ & \multicolumn{2}{|l|}{$45-54$} \\
\hline
\end{tabular}

the ARMS Register membership shows the commonly reported broad peak in the $30-59$ year age group ${ }^{13}$ although female members tend to be younger than those found in the other populations. This finding may reflect the trend towards younger rather than older membership of mutual support groups noted earlier.

\section{AGE AT DIAGNOSIS AND DURATION}

The information available from our survey of general practitioners (reported above) did not allow us to estimate the exact date or age at onset of MS for this population. Age at onset was estimated in eight of the comparative studies and duration of the condition in five of these (table 3), although a number of problems were highlighted by the authors which suggest that results in relation to each of these variables must be treated as tentative. There is a particular problem with early mild and transient symptoms which may not initially be associated with MS. ${ }^{81315}$ Lack of recall of such symptoms would result in underestimation of the mean duration for a particular population, while

Table 7 ARMS Research Register: sex and age distribution (percentages relating to women and men separately are shown in brackets)

\begin{tabular}{|c|c|c|c|c|c|c|c|}
\hline \multirow[b]{2}{*}{ Sex } & \multicolumn{6}{|c|}{ Age group (years) } & \multirow[b]{2}{*}{ Total } \\
\hline & $20-29$ & $30-39$ & $40-49$ & $50-59$ & $60-69$ & $70-79$ & \\
\hline $\begin{array}{l}\text { Female } \\
\text { Male }\end{array}$ & $\begin{array}{l}40(5) \\
15(5)\end{array}$ & $\begin{aligned} 242 & (30) \\
66 & (25)\end{aligned}$ & $\begin{array}{r}234(29) \\
74(28)\end{array}$ & $\begin{array}{r}197(24) \\
66(25)\end{array}$ & $\begin{array}{r}101(12) \\
41(15)\end{array}$ & $\begin{array}{l}4(<0.5) \\
5(2)\end{array}$ & $\begin{array}{l}818(100) \\
267(100)\end{array}$ \\
\hline Total & $55(5)$ & $308(28)$ & 308 (28) & $263(24)$ & $142(13)$ & $9(2)$ & $1085(100)^{*}$ \\
\hline
\end{tabular}

* Data missing for 6 members 


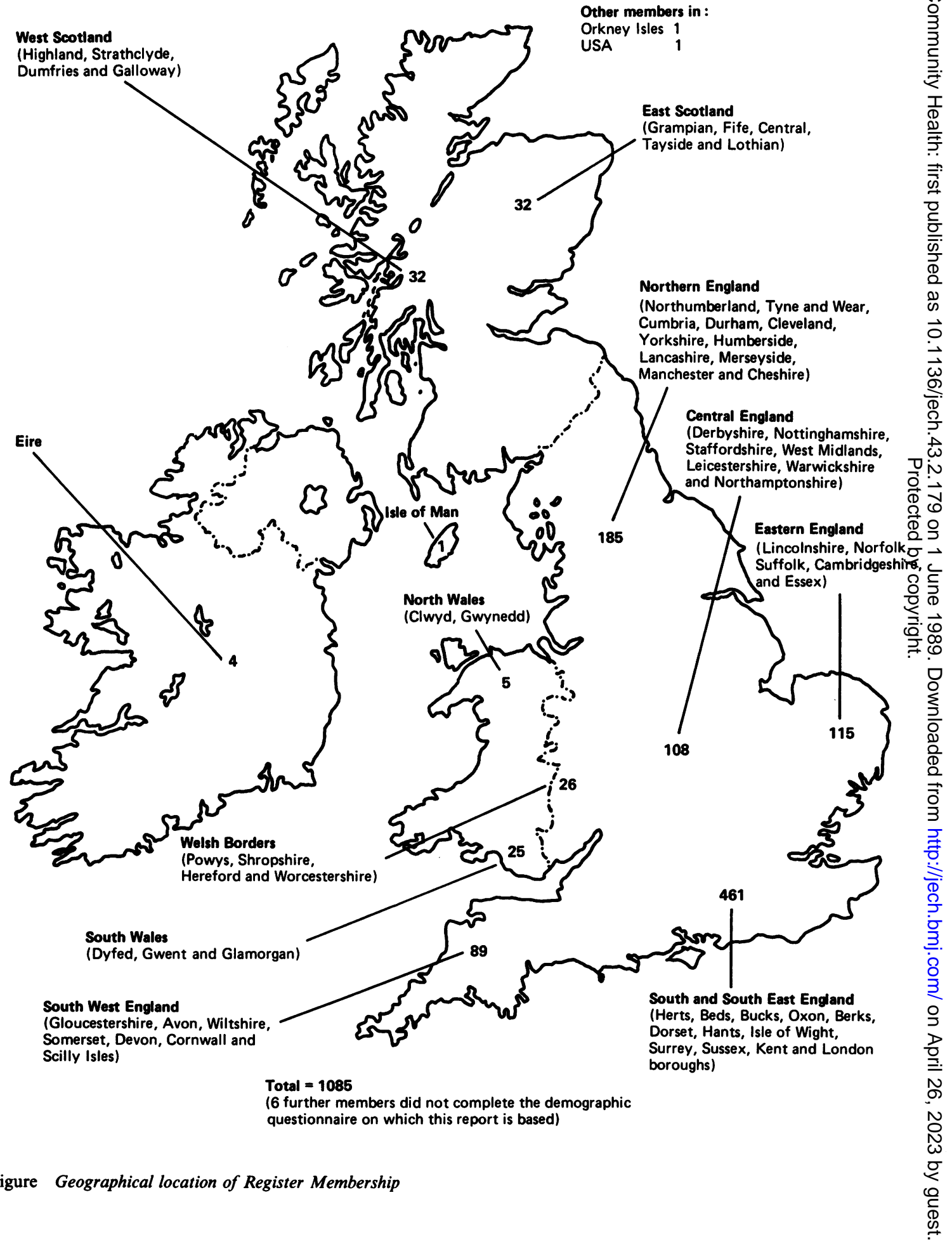


conversely the usually lengthy diagnostic process would tend to produce an overestimation of duration owing to unrecognised early cases. ${ }^{8}$ In view of these problems Poskanzer et at suggest that the mean duration of MS in any population should be regarded as a relative rather than an actual value, although useful for the comparison of populations as employed here.

The mean age at onset of MS is thought to be between 29 and 33 years ${ }^{1}$ and it is generally accepted that a diagnosis may not be achieved for several years after the first occurrence of symptoms, ${ }^{181122}$ the usual interval probably being about 7 years. ${ }^{811}$ The mean age at diagnosis of the ARMS Register population was therefore rather lower than expected at 36 years. This may reflect the relative youth of the population, and/or the higher proportion of women, who are thought to show symptoms at an earlier age than men. ${ }^{1}$

Our own data on duration based on date of diagnosis are not directly comparable with those from the other studies indicated in table 3 , which base disease duration from the date of onset. The mean disease duration since diagnosis in the ARMS Register population was 9.7 years (range $<1-36$ years), approximately 7 years less than that for the comparative study populations $(16.9$ years, excluding the findings of Shibasaki et a ${ }^{4}$ which give duration up to the latest clinical examination). This interval was similar to that quoted earlier as the usual interval between onset and diagnosis. In conjunction with the results given above, this suggests that the mean duration of the disease might be broadly similar in all the populations, with the ARMS cohort showing symptoms at a rather earlier age.

\section{Discussion}

Systematic epidemiological research on multiple sclerosis is bedevilled by difficulties of case ascertainment and it is clear that currently no legitimate claim to complete case identification could be made, however localised the population under study. The most that can be achieved at present is an approximation to a complete population in which the potential biases may not be capable of clear evaluation.

Such studies as have been undertaken have often used a variety of unconventional sources to locate patients, among which the records of one particular voluntary organization (the Multiple Sclerosis Society) feature prominently. It is reasonable to suppose that for the forseeable future the membership of this and other voluntary organisations relevant to people with MS would need to be tapped, not only in localised epidemiological research, but in larger scale studies concerned with, for instance, the social effects of MS and service provision. Davoud and Kettle ${ }^{7}$ indeed drew their entire population from the membership of the Multiple Sclerosis Society. It is important that the characteristics of those likely to be drawn from such agencies should be investigated so as to estimate the usefulness of these sources and so that possible bias may be taken into account when interpreting the results of studies which employ them.

The specific aim of this paper has been to compare demographic and diagnostic characteristics of the ARMS Register membership with the characteristics of other British MS populations. In general, on all of the variables investigated the ARMS Register population fell close to, or within the range shown by the comparative populations. Where differences were evident in the age and sex composition of the ARMS population they were in the direction that would be predicted by existing publications on mutual support groups-an apparent overrepresentation of younger and female cases. The excellent response from general practitioners in confirming diagnostic status has made it possible to suggest that in this population at least only a very small minority of self diagnoses are in doubt, although further work would be needed to establish the accuracy of the general practitioners' diagnostic categorisation. A population drawn from a mutual support organisation may then be a useful complement to other MS research populations, provided that the likely biases inherent in each are understood and inform subsequent analyses.

We are grateful to those who have helped with computing and secretarial tasks. The study was funded by Action for Research into Multiple Sclerosis.

Address for correspondence and reprints: Judith Monks, Research Fellow, Brunel-ARMS Research Unit, Department of Human Sciences, Brunel, The University of West London, Uxbridge, Middlesex UB8 3PH, UK.

\section{References}

${ }^{1}$ Matthews WB, Acheson ED, Batchelor JR, Wellor RO. McAlpine's multiple sclerosis. London: Churchill Livingstone, 1985.

${ }^{2}$ Herndon RM, Rudick RA. Multiple sclerosis. The spectrum of severity. Arch Neurol 1983; 40: 531-2.

${ }^{3}$ Miller DH, Ormerod IEC, du Boulay GT et al. A summary of the present contribution of magnetic resonance imaging to diagnosis and understanding of multiple sclerosis. In: Rose FC, Jones R, eds. Multiple sclerosis. Immunological, diagnostic and therapeutic aspects. London: John Libbey, 1987; 121-7.

${ }^{4}$ Shibasaki H, McDonald WI, Kuroiwa Y. Racial modification of clinical picture of multiple sclerosis: comparison between British and Japanese patients. $J$ Neurol Sci 1981; 49: 253-71. 
${ }^{5}$ Visscher BR, Clark VA, Detels $\mathrm{R}$ et al. Two populations with multiple sclerosis. Clinical and demographic characteristics. $J$ Neurol 1981; 225: 237-49.

${ }^{6}$ Levy L. Mutual support groups in Great Britain: A survey. Soc Sci Med 1982; 16: 1265-75.

${ }^{7}$ Davoud N, Kettle M. Multiple sclerosis and its effect upon employment. London: Multiple Sclerosis Society, 1980.

${ }^{8}$ Poskanzer DC, Prenney LB, Sheridan JL, Yon Kondy J. Multiple sclerosis in the Orkney and Shetland Islands. 1: Epidemiology, clinical factors, and methodology. $J$ Epidemiol Community Health 1980; 34: 229-39.

${ }^{9}$ Roberts DF. Multiple sclerosis in the Orkney and Shetland Isles. In: Rose FC, ed. Clinical neuroepidemiology. London: Pitman Medical Ltd, 1980: 208-18.

${ }^{10}$ Shepherd DI, Downie AW. A further prevalence study of multiple sclerosis in North-East Scotland. J Neurol Neurosurg Psychiatry 1980; 43: 310-5.

${ }^{11}$ Dean G, Goodall J, Downie A. The prevalence of multiple sclerosis in the Outer Hebrides compared with NorthEast Scotland and the Orkney and Shetland Islands. $J$ Epidemiol Community Health 1981; 35: 110-3.

12 Roberts DF, Bates D. The genetic contribution to multiple sclerosis. Evidence from North-East England. J Neurol Sci 1982; 54: 287-93.

${ }^{13}$ Cook SD, Cromarty JI, Tapp W, Poskanzer D, Walker JD, Dowling PC. Declining incidence of multiple sclerosis in the Orkney Islands. Neurology 1985; 35: 545-51.

14 Williams ES, McKeran RO. Prevalence of multiple sclerosis in a South London borough. Br Med J 1986; 293: 237-9.
15 Phadke JG, Downie AW. Epidemiology of multiple sclerosis in the North-East (Grampian Region) of Scotland-An update. J Epidemiol Community Health 1987; 41: 5-13.

${ }^{16}$ Multiple Sclerosis Indicative Abstracts. Published for the National Multiple Sclerosis Society by the Federation of American Societies for Experimental Biology: Maryland, Bethesda, 1980-1985; 6-11. (Publication ceased September 1985).

${ }^{17}$ Multiple Sclerosis Research Reports. Published for the International Federation of Multiple Sclerosis Societies by Demos Publications Inc, New York, 1987-1988; 1-2.

${ }^{18}$ Discovering the Diagnosis of MS. General Report No.3. Brunel-ARMS Research Unit, Brunel, The University of West London, 1983.

${ }^{19}$ McLellan DL, Roberts MHW. Pravalence of multiple sclerosis in a South London borough (Letter). Br Med J 1986; 293: 507.

${ }^{20}$ Gonzalez-Scarano F, Speilman RS, Nathanson $\mathrm{N}$. Epidemiology. In: McDonald WI, Silberberg DH eds. Multiple sclerosis. London: Butterworths, 1986.

${ }^{21}$ Robinson I, Bakes C, Lawson A. Multiple sclerosis: more women than men? Questioning the facts. 1983 (mimeo). Available from Brunel-ARMS Research Unit.

${ }^{22}$ Downie AW, Phadke JG. The Chief Scientist Reports ... Multiple sclerosis in North East Scotland. Health Bull 1984; 42/3: 151-6.

Accepted for publication December 1988 